\title{
INOVASI PEMBELAJARAN SAINTIFIK DENGAN SNOWBALL THROWING DALAM PROSES MENANYA TERHADAP HASIL BELAJAR SISWA
}

\author{
I NYOMAN JAMPEL, ${ }^{1}$, I WAYAN WIDIANA, ${ }^{2}$, NI MADE YENI JULIANTARI, ${ }^{3, *}$ \\ 1 Jurusan Pendidikan Guru Sekolah Dasar. Universitas Pendidikan Ganesha, Indonesia \\ 2 Jurusan Pendidikan Guru Sekolah Dasar. Universitas Pendidikan Ganesha, Indonesia \\ 3 Jurusan Pendidikan Guru Sekolah Dasar. Universitas Pendidikan Ganesha, Indonesia
}

\begin{abstract}
This research is aimed at determine the differences students learning outcome between of students applying scientific approach in process of questioning assisted by Snowball Throwing and students applying conventional learning. This research is a quasi experimental which used non equivalent post-test only control group design. The population were 3rd grade Of Elementary School student in school piloting of Curriculum 2013, Buleleng District with the number of the student were 358 students, through random sampling technique. The data of students' learning outcomes were collected using regular multiple choice test and essay test. The data were analyzed by using descriptive statistics namely modus, media, mean and inferential statistic, namely t-test. The result of $t$-test analysis that $t_{\text {count }}$ is greater than ttable, $2.7327>1,9965$ with $66 \mathrm{df}$. It can be concluded that scientific approach in process of questioning assisted by Snowball Throwing gave a significant learning outcomes of 3rd grade elementary school.
\end{abstract}

\author{
Keywords: \\ Learning outcomes, \\ Questioning, Scientific \\ approach, Snowball \\ Throwing
}

\section{Pendahuluan}

Pada tahun 2013, pemerintah mengimplementasikan kurikulum baru sebagai penyempurnaan kurikulum sebelumnya yaitu Kurikulum Tingkat Satuan Pendidikan (KTSP) menjadi Kurikulum 2013. Dalam peraturan menteri pendidikan dan kebudayaan dinyatakan bahwa Kurikulum 2013 bertujuan untuk mempersiapkan manusia Indonesia agar memiliki kemampuan hidup sebagai pribadi dan warga negara yang beriman, produktif, kreatif, inovatif, dan afektif serta mampu berkontribusi pada kehidupan bermasyarakat, berbangsa, bernegara, dan peradaban dunia (Permendikbud Nomor 57 tahun 2014). Standar Kompetensi Lulusan (SKL) yang ingin dicapai melalui penerapan Kurikulum 2013 mencakup sikap, pengetahuan dan keterampilan (Sani, 2015). Berdasarkan hal tersebut, tujuan hasil pembelajaran yang harus dicapai siswa yakni aspek spiritual, sosial, pengetahuan dan keterampilan. Agar siswa mampu mencapai tujuan tersebut, maka Kurikulum 2013 menganut sistem pembelajaran aktif. Pembelajaran aktif adalah suatu pembelajaran yang mengajak peserta didik untuk belajar secara aktif, berarti mereka yang mendominasi aktifitas pembelajaran. Dengan belajar aktif peserta didik diajak untuk turut serta dalam semua proses pembelajaran, tidak hanya mental akan tetapi juga melibatkan fisik, Zain (dalam Rita, Amrazi, Rustiyarso: 2016). Untuk menciptakan pembelajaran aktif, maka Kurikulum 2013 memiliki ciri khas yaitu menerapkan pembelajaran tematik terpadu dengan pendekatan saintifik.

Pembelajaran tematik terpadu menggunakan tema sebagai pemersatu kegiatan pembelajaran yang memadukan beberapa mata pelajaran sekaligus dalam satu kali tatap muka untuk memberikan pengalaman yang bermakna bagi peserta didik (Suarjana dan Japa, 2015). Keterlibatan peserta didik dalam belajar lebih diprioritaskan dan pembelajaran bertujuan untuk mengaktifkan peserta didik, memberikan pengalaman langsung serta tidak tampak adanya pemisahan antar mata pelajaran satu dengan lainnya. Pembelajaran merupakan proses ilmiah oleh karena itu Kurikulum 2013 menggunakan pendektan saintifik atau ilmiah dalam pembelajaran. Kurniasih dan Sani (2014: 29), menyatakan bahwa, "Pembelajaran dengan pendekatan saintifik adalah proses pembelajaran yang dirancang agar siswa aktif mengonstruk konsep, hukum atau prinsip melalui tahapan - tahapan mengamati, merumuskan masalah,

\footnotetext{
* Corresponding author.

E-mail Addresses: nyoman.jampel@gmail.com (I Nyoman Jampel), wayan_widiana@yahoo.co.id (I Wayan Widiana), yenijuliantariii@gmail.com (Ni Made Yeni Juliantari)
} 
mengajukan atau merumuskan hipotesis, mengumpulkan data, menganalisis data, menarik kesimpulan dan mengomunikasikan konsep yang ditemukan"

Pendekatan Saintifik menurut Kurniasih dan Sani (2014) memiliki beberapa tujuan, yaitu : 1) dapat meningkatkan kemampuan intelek, khususnya kemampuan berpikir tinggi siswa, 2) mengembangkan karakter siswa, 3) melatih siswa dalam mengkomunikasikan ide - ide. Melalui pendekatan saintifik diyakini mampu mengakomodasi perkembangan dan pengembangan sikap, keterampilan, dan pengetahuan peserta didik pada proses pembelajaran.

Sampai saat ini, kurikulum 2013 telah diterapkan di sekolah rintisan Kurikulum 2013 selama 3 tahun. Pemerintah berharap melalui Kurikulum 2013 dapat meningkatkan kualitas aktivitas pembelajaran di sekolah menjadi lebih aktif dan bermakna bagi siswa sehingga akan meningkatkan hasil belajar siswa. Berdasarkan hasil observasi pada 12 Januari 2017 di sekolah rintisan Kurikulum 2013 kabupaten Buleleng menemukan bahwa selama ini dalam pelaksanaan kurikulum 2013, pelaksanaan lima langkah dalam pendekatan saintifik belum berjalan secara efektif dan belum ada pengembangan yang inovatif dalam pembelajarannya, sehingga pembelajaran dalam kurikulum 2013 dan pembelajaran dalam kurikulum sebelumnya tidak jauh berbeda. Temuan tersebut didukung oleh Rini Kristiantari (2014) yang mengemukakan bahwa secara teoretis guru-guru sudah memiliki pemahaman tentang kurikulum 2013, walaupun telah memiliki pemahaman, guru-guru masih kesulitan dalam mengaplikasikan kurikulum 2013. Hal ini dapat dilihat dalam pelaksanaan pembelajaran sehari-hari. Proses pembelajaran yang berlangsung, guru cenderung masih mendominasi dengan menggunakan metode ceramah. Siswa hanya mendengarkan penjelasan guru kemudian dilanjutkan dengan mengerjakan latihan Guru juga kurang mampu menarik perhatian siswa dengan menggunakan media atau alat peraga serta inovasi kegiatan pembelajaran. Hasil penelitian Widyani (2017) juga menemukan hambatan yang sama dalam implementasi Kurikulum 2013 yaitu kesulitan ketersediaan dan memilih media pembelajaran.

Penelitian yang dilakukan oleh Wahyudiatmika (2015) juga menemukan pada proses pembelajaran di kelas khususnya pada kegiatan menanya tidak sesuai dengan yang diharapkan, hanya beberapa siswa yang aktif untuk mengajukan pertanyaan sedangkan siswa yang lain diam. Hal ini tentu tidak sesuai dengan harapan dalam kurikulum 2013 yang menggunakan pendekatan saintifik. Melalui kegiatan bertanya dikembangkan rasa ingin tahu peserta didik. Semakin terlatih dalam bertanya maka rasa ingin tahu semakin dapat dikembangkan. Pertanyaan juga dapat dijadikan oleh siswa sebagai sarana mencari informasi. Hal-hal tersebut mengakibatkan keaktifan siswa mengikuti pembelajaran di kelas menjadi berkurang sehingga masih ditemukan masalah hasil belajar siswa rendah.

Rendahnya keaktifan siswa dalam mengikuti pembelajaran mengakibatkan rendahnya keberhasilan belajarnya. Hal inilah yang terjadi pada siswa kelas III SD di sekolah rintisan Kurikulum 2013 Kabupaten Buleleng. Berdasarkan hasil tes studi pendahuluan, diperoleh data hasil belajar siswa yaitu kelas III A SD 4 Kampung Baru memperoleh rata-rata 63,96, III B SD 4 Kampung Baru memperoleh rata-rata 64,04, III A SD N 3 Banjar Jawa memperoleh rata-rata 75.78, III B SD N 3 Banjar Jawa memperoleh rata-rata 78.12, III C SD N 3 Banjar Jawa memperoleh rata-rata 82.65, kelas III SD 4 Banyuasri memperoleh rata-rata 62.81, kelas III SD 4 Kaliuntu memperoleh rata-rata 57.96, kelas III SD N 6 Pejarakan memperoleh rata-rata 59.30, kelas III SD N 1 Busungbiu memperoleh rata-rata 56.66, III A SD Laboratorium Undiksha memperoleh rata-rata 68.24 dan III B SD Laboratorium Undiksha memperoleh rata-rata 64.02 .

Berdasarkan data di atas, jika mengacu pada Penilaian Acuan Patokan (PAP) dapat dilihat bahwa 7 dari 11 kelas memiliki nilai rata-rata termasuk kategori rendah. Kriteria Penilaian Acuan Patokan dapat dilihat pada tabel 1. berikut.

Tabel 1. Kriteria enilaian Acuan Patokan (PAP).

\begin{tabular}{|c|c|}
\hline Presentase Pengusaan & Kategori \\
\hline $90-100$ & Sangat Tinggi \\
\hline $80-89$ & Tinggi \\
\hline $65-79$ & Sedang \\
\hline $55-64$ & Rendah \\
\hline $00-54$ & Sangat Rendah \\
\hline
\end{tabular}

(Sumber: Agung, 2014)

Berdasarkan hasil tes studi pendahuluan siswa kelas III di masing-masing SD Rintisan Kurikulum 2013 Kabupaten Buleleng diketahui bahwa hasil belajar pada aspek kognitif berada pada kategori rendah. Hasil belajar terbagi dalam tiga ranah, yaitu ranah kognitif, afektif dan psikomotor. Secara khusus, penelitian ini akan mengukur hasil belajar siswa dalam ranah kognitif. Untuk mengukur hasil belajar 
kognitif guru menggunakan Taksonomi Bloom dalam mendesain tujuan pembelajaran. Anderson dan Krathwohl (2010) telah berhasil mengembangkan taksonomi tersebut dengan merevisi taksonomi tersebut menjadi taksonomi belajar mengajar dan asessmen. Menurut Anderson (2010) taksonomi tersebut direpresentasikan dalam 2 dimensi yaitu dimensi pengetahuan dan dimensi proses kognitif. Dimensi proses kognitif meliput: (1) mengingat, (2) memahami, (3) menerapkan, (4) menganalisis, (5) mengevaluasi, (6) mencipta.

Berdasarkan hasil wawancara dengan guru dapat diidentifikasi beberapa faktor penyebab rendahnya hasil belajar siswa yaitu pertama, guru sulit untuk memfokuskan siswa dalam belajar sehingga dalam pembelajaran guru memilih untuk menggunakan metode ceramah tetapi akibatnya lima tahap pendekatan saintifik belum dapat dilihat secara jelas pada proses pembelajaran. Kedua, pada proses pembelajaran, guru merasa kesulitan untuk menumbuhkan keberanian siswa dalam bertanya, dimana dalam satu kelas biasanya hanya beberapa siswa yang aktif bertanya, hal ini tentu berdampak pada rendahnya rasa ingin tahu, minat dan perhatian siswa dalam proses pembelajaran. Ketiga, kegiatan menanya dalam pendekatan saintifik sulit untuk diterapkan sehingga guru lebih banyak mengajukan pertanyaan dan menjelaskan jawaban dari pertanyaan tersebut sehingga siswa kurang mendapatkan kesempatannya untuk mengembangkan kemampuan berpikirnya, mengembangkan informasi serta kepribadiannya untuk selalu berani dan percaya diri. Keempat, masih minimnya pertanyaan-pertanyaan yang dilontarkan siswa kepada guru, kurangnya pendapat-pendapat yang muncul dari siswa saat proses pembelajaran, dan kurang mampunya siswa dalam menjelaskan pendapatnya secara logis, hal tersebut terjadi karena siswa merasa malu dan takut untuk menjawab pertanyaan oleh guru. Kelima, guru jarang menggunakan taksonomi dalam membuat instrument penilaian.

Berdasarkan pemaparan permasalahan di atas, diketahui bahwa proses pembelajaran yang berlangsung tidak mampu menumbuhkan minat, rasa ingin tahu dan keaktifan siswa dalam mengikuti pembelajaran terutama keaktifan siswa untuk bertanya. Bertanya merupakan hal yang penting dalam belajar. Menurut Wahyudiatmika (2015), berlakunya kurikulum 2013 menjadikan kemampuan menanya bertambah penting. Dalam implementasi kurikulum 2013 menggunakan pendekatan saintifik dimana dalam pendekatan saintifik terdapat 5 tahapan pembelajaran, salah satunya adalah tahapan menanya. Dengan bertanya menunjukkan siswa telah berpikir mengenai pelajaran yang diterima dan memperjelasnya dengan mengajukan pertanyaan yang berkaitan dengan materi yang telah diajarkan.

Menurut Indah (2015), bertanya merupakan metode untuk membuat siswa berpikir, jika siswa berpikir berarti mereka memiliki sifat ingin tahu dan untuk memuaskan rasa ingin tahu tersebut, salah satu caranya adalah dengan bertanya. Menurut Wahyudiatmika (2015), dengan bertanya siswa terlatih untuk berpikir, terlatih untuk mengembangkan informasi dan pengetahuan yang didapatnya, dan dengan kebiasaan bertanya akan melatih kepribadiannya agar selalu berani dan percaya diri. Dengan mengajukan pertanyaan, pengetahuan yang diperolehnya akan lebih meninggalkan kesan. siswa akan lebih mengingat dengan apa yang telah ditanyakannya, dengan jawaban yang telah diberikan gurunya. Hal tersebut juga didukung oleh Mafikha Sari (2015) yang menyebutkan pertanyaan merupakan saat-saat yang sangat berguna karena siswa memusatkan seluruh perhatiannya terhadap sesuatu yang baru, pertanyaan juga menunjukkan bahwa siswa menyadari adanya suatu permasalahan.

Mengingat bertanya merupakan salah satu faktor penyumbang yang penting bagi keberhasilan siswa dalam belajar, sebagai seorang guru sudah seharusnya untuk mampu memberi kesempatan dan mendorong siswa aktif dalam belajar terutama aktif untuk bertanya. Maka salah satu upaya yang dapat dilakukan untuk mendorong dan meningkatkan keaktifan siswa dalam bertanya dengan menerapkan inovasi dari model pembelajaran snowball throwing. Menurut Ismail (dalam Murniasih, 2012),snowball berarti bola salju, sedangkan throwing artinya melempar. Snowball throwing dapat diartikan melempar bola salju. Dalam pembelajaran snowball throwing, bola salju merupakan kertas yang berisi pertanyaan yang dibuat oleh siswa kemudian dilempar kepada temannya sendiri untuk dijawab. Berdasarkan definisi tersebut,dengan snowlball throwing memiliki kelebihan yaitu 1) Mengungkapkan daya ingat, 2) Pembelajaran berpusat pada peserta didik, 3) Peserta didik aktif.

Shoimin (2014), melalui penerapan model snowball throwing, siswa dapat menyampaikan pertanyaan atau permasalahannya dalam bentuk tertulis yang nantinya akan didiskusikan bersama. Hal tersebut juga didukung oleh Kosasih (2014), membuat pertanyaan secara tertulis, dapat memberikan kesempatan kepada para siswa untuk lebih leluasa memikirkan dan merumuskan pertanyaan secara rinci dan jelas serta mengatasi rasa malu menyampaikan pertanyaan secara lisan. Berdasarkan pemaparan para ahli tersebut dapat disintesiskan bahwa pembelajaran dengan snowball throwing dapat mengatasi permasalahan siswa permasalahan atau kesulitan yang ditemui siswa dengan menuliskannya pada sebuah kertas.

Suasana pembelajaan dapat berlangsung lebih menyenangkan karena siswa tidak hanya berpikir, menulis dan berbicara, namun juga melakukan kegiatan fisik yaitu menggulung kertas dan melemparnya 
pada teman lainnya sehingga siswa tidak merasa jenuh dan bosan. Hal ini juga sesuai dengan salah satu prinsip pembelajaran dengan snowball throwing yaitu menyenangkan (joyfull learning), Rahman (2014). Mengingat peserta didik berada di kelas III atau kelas rendah. Tentunya di kelas rendah kebiasaan anak yang masih suka bermain membuat model ini menjadi solusi yang baik untuk diujicobakan. Hal ini juga didukung oleh penelitian Wardhiana (2013) yang menyataan bahwa penerapan model Pembelajaran Kooperatif Tipe snowball throwing pada pembelajaran PKn dapat meningkatkan keaktifan dan hasil belajar siswa kelas V semester II SD Negeri 1 Bungbungan Kecamatan Banjarangkan tahun pelajaran 2012/2013.

Dalam pembelajaran dengan pendekatan saintifik, inovasi aktivitas pembelajaran berbantuan snowball throwing akan diterapkan pada langkah menanya. Tahap menanya dalam Pendekatan Saintifik merupakan tahap dari situasi di mana peserta didik dilatih menggunakan pertanyaan dari guru, masih memerlukan bantuan guru untuk mengajukan pertanyaan sampai ke tingkat di mana peserta didik mampu mengajukan pertanyaan secara mandiri. Melalui kegiatan bertanya dikembangkan rasa ingin tahu peserta didik. Semakin terlatih dalam bertanya maka rasa ingin tahu semakin dapat dikembangkan sehingga siswa akan mendapatkan pengetahuan yang lebih bermakna. Pendekatan saintifik dalam proses menanya berbantuan snowball throwing akan dapat mengaktifkan siswa dalam belajar dan membantu mengatasi rasa malu siswa untuk bertanya mengenai permasalahan yang dijumpainya ketika belajar. Dengan demikian, siswa dapat mengungkapkan kesulitan-kesulitan yang dialaminya dalam memahami materi pelajaran.

\section{Metode Penelitian}

Penelitian ini merupakan jenis penelitian eksperimen semu karena tidak semua variabel yang muncul dalam kondisi eksperimen dapat diatur dan dikontrol secara ketat. Desain Penelitian yang digunakan adalah non equivalent post-test only control group design. Populasi dalam penelitian ini adalah kelas III SD di Sekolah Rintisan Kurikulum 2013 Kabupaten Buleleng Tahun Pelajaran 2016/2017 yang berjumlah 358 orang. Populasi tersebut kemudian diuji kesetaraannya untuk menentukan sampel penelitian. Pemilihan sampel penelitian dilakukan secara undi dengan teknik random sampling. Sampel dalam penelitian ini adalah kelas III SD N 1 Busungbiu dan SD N 4 Kaliuntu sebagai kelas kontrol. Variabel yang dilibatkan dalam penelitian ini ada dua yaitu pendekatan saintifik dalam proses menanya berbantuan Snowbal Throwing dan pembelajaran konvensional sebagai variabel bebas dan hasil belajar sebagai variabel terikat.

Metode Pengumpulan data yang digunakan dalam penelitian ini adalah metode tes. Metode tes digunakan untuk memperoleh data hasil belajar siswa pada tema energi dan perubahannya. Tes yang digunakan adalah tes objektif dalam bentuk pilihan ganda dan tes uraian. Tes ini diberikan setelah dilakukan perlakuan pada kelas eksperimen dan kelas kontrol pada akhir perlakuan yang digunakan untuk menguji kebenaran hipotesis penelitian. Instrumen penelitian yang akan dipergunakan untuk mengumpulkan data hasil belajar siswa disusun berdasarkan kisi-kisi yang telah dibuat. Sebelum digunakan untuk mengambil data, instrumen- instrumen tersebut dilakukan uji coba untuk mengetahui validitas, reliabilitas, tingkat kesukaran tes, dan daya beda. Data hasil belajar analisisnya menggunakan ttest sebelum analisis data dilakukan terlebih dahulu diuji prasarat analisis yaitu uji normalitas sebaran data, dan uji homogenitas varians. Untuk uji normalitas sebaran data dengan uji Chi Kuadrat, uji homogenitas varians menggunakan uji F. Dalam proses analisis data menggunakan bantuan Microsoft Office Excel 2007.

Untuk menentukan tinggi rendahnya kualitas variabel-variabel tersebut, skor rata-rata (mean) tiap-tiap variabel dikonversi dengan criteria rata-rata ideal $\left(\mathrm{M}_{\mathrm{i}}\right)$ dan standar deviasi ideal $\left(\mathrm{SD}_{\mathrm{i}}\right)$. Skala penilaian atau kategori pada skala penilaian dapat dilihat pada Tabel 2 .

Tabel 2. Skala Penilaian atau Kategori Skala Lima

\begin{tabular}{cc}
\hline Rentang Skor & Kategori \\
\hline$M_{i}+1,5 S D_{i} \leq M \leq M_{i}+3,0 S D_{i}$ & Sangat Baik \\
$M_{i}+0,5 S D_{i} \leq M \leq M_{i}+1,5 S D_{i}$ & Baik \\
$M_{i}-0,5 S D_{i} \leq M \leq M_{i}+0,5 S D_{i}$ & Cukup \\
$M_{i}-1,5 S D_{i} \leq M \leq M_{i}-0,5 S D_{i}$ & Tidak Baik \\
\hline
\end{tabular}




\section{Hasil dan Pembahasan}

Data penelitian ini adalah skor hasil belajar siswa sebagai akibat dari pembelajaran dengan Pendekatan Saintifik dalam proses menanya berbantuan snowball throwing pada kelompok eksperimen dan pembelajaran konvensional pada kelompok kontrol. Rekapitulasi perhitungan data hasil siswa dapat dilihat pada Tabel 3.

Tabel 3. Rekapitulasi Hasil Perhitungan Data Hasil Belajar Siswa

\begin{tabular}{cccccc}
\hline Kelompok & Mean (M) & Median (Md) & Modus (Mo) & $\begin{array}{c}\text { Standar } \\
\text { Deviasi }\end{array}$ & Varian \\
\hline Eksperimen & 25,30 & 26 & 29 & 4,93 & 24,33 \\
\hline Kontrol & 22,21 & 21,87 & 21 & 4,59 & 21,07 \\
\hline
\end{tabular}

Berdasarkan Tabel 3, diketahui bahwa mean data hasil belajar kelompok siswa yang mengikuti pembelajaran melalui pendekatan saintintik dalam proses menanya berbantuan Snowball Throwing sebesar 25,30 lebih besar daripada kelompok siswa yang mengikuti pembelajaran konvensional dengan Mean sebesar 22,21. Hal itu berarti bahwa nilai rata-rata hasil belajar siswa kelompok eksperimen lebih tinggi dari pada nilai rata-rata hasil belajar siswa kelompok konvensional.

Sebaran data pada kelompok eksperimen diketahui bahwa modus lebih besar dari median dan median lebih besar dari mean $(\mathrm{Mo}>\mathrm{Md}>\mathrm{M})$, yang berarti sebagian besar skor cenderung tinggi. Sedangkan sebaran data pada kelompok kontrol diketahui mean lebih besar dari median dan modus lebih besar dari modus ( $\mathrm{M}>\mathrm{Md}>\mathrm{Mo}$ ), yang berarti sebagian besar skor cenderung rendah.

Berdasarkan kriteria skala lima dan sesuai dengan hasil analisis data bahwa mean hasil belajar siswa pada kelompok yang dibelajarkan dengan menggunakan pendekatan saintifik dalam proses menanya berbantuan snowball throwing adalah 25,30 (berada pada kategori sangat tinggi). Sebaliknya Mean hasil belajar siswa pada kelompok yang dibelajarkan dengan menggunakan pembelajaran konvensional adalah 22,21 (berada pada katagori tinggi).

Pada penelitian ini, terlebih dahulu dilakukan uji prasyarat analisis sebelum uji hipotesis dianalisis dengan uji " $t$ " (t-test). Sebelum dilakukan uji hipotesis terlebih dahulu dilakukan uji prasyarat analisis. Uji prasyarat analisis meliputi dua hal, yaitu (1) uji normalitas distribusi data terhadap keseluruhan unit analisis, dan (2) uji homogenitas varian antar kelompok.

Uji normalitas data dilakukan pada keseluruhan unit analisis yaitu kelompok eksperimen dan kelompok kontrol. Uji normalitas untuk hasil belajar siswa digunakan analisis chi-square. Kriteria data berdistribusi normal jika $x^{2}$ hit $<x^{2}$ tabel dengan taraf signifikansi $5 \%$ (dk = jumlah kelas dikurangi parameter, dikurangi 1 ), maka $\mathrm{H}_{0}$ diterima yang menunjukan data berdistribusi normal.Ringkasan hasil uji normalitas data pada kelompok eksperimen dan kelompok kontrol disajikan pada Tabel 4.

Tabel 4. Ringkasan Uji Normalitas

\begin{tabular}{lccl}
\hline Kelompok Data Hasil Belajar & $\chi^{2}{ }_{h i t}$ & $\chi^{2}{ }_{t a b}$ & Status \\
\hline Post-test Eksperimen & 6,953 & 9,488 & Normal \\
Post-test Kontrol & 3,939 & 7,815 & Normal \\
\hline
\end{tabular}

Berdasarkan hasil perhitungan dengan menggunakan rumus chi-kuadrat, diperoleh $\chi^{2}{ }_{h i t}$ hasil post-test kelompok eksperimen adalah 6,953 dan $\chi_{\text {tab }}^{2}$ dengan taraf signifikansi $5 \%$ dan db $=4$ adalah 9,488. Hal ini berarti, $\chi^{2}{ }_{h i t}$ hasil post-test kelompok eksperimen lebih kecil dari $\chi_{\text {tab }}^{2}\left(\chi^{2}{ }_{h i t}<\chi_{t a b}^{2}\right)$, sehingga data hasil post-test kelompok eksperimen berdistribusi normal. Sedangkan, $\chi^{2}$ hit hasil post-test kelompok kontrol adalah 3,939 dan $\chi_{\text {tab }}^{2}$ dengan taraf signifikansi 5\% dan db $=3$ adalah 7,815. Hal ini 
berarti, $\chi_{h i t}^{2}$ hasil post-test kelompok kontrol lebih kecil dari $\chi_{\text {tab }}^{2}\left(\chi_{h i t}^{2}<\chi_{t a b}^{2}\right)$, sehingga data hasil post-test kelompok kontrol berdistribusi normal.

Uji homogenitas dilakukan terhadap varians pasangan antara kelompok eksperimen dan kelompok kontrol. Uji yang digunakan adalah uji $\mathrm{F}$ dengan kriteria data homogen jika $\mathrm{F}_{\text {hit }}<\mathrm{F}_{\text {tab. Rangkuman hasil uji }}$ homogenitas varians antara kelompok eksperimen dan kelompok kontrol disajikan pada tabel 5 . berikut ini.

Tabel 5. Rangkuman Hasil Uji Homogenitas Varians

\begin{tabular}{lllllll}
\hline \multicolumn{1}{c}{ Sampel } & Mean & SD & Varians & $F_{\text {hitung }}$ & $F_{\text {tabel }}$ & Kesimpulan \\
\hline $\begin{array}{llllll}\text { Kelompok } \\
\text { eksperimen }\end{array}$ & 25,38 & 5,061 & 25,615 & \multirow{2}{*}{1,215} & 1,800 & $F_{\text {hitung }}<F_{\text {tabel }}$ \\
\cline { 1 - 4 } Kelompok kontrol & 22,21 & 4,591 & 21,079 & & & \\
\hline
\end{tabular}

Berdasarkan tabel di atas, diketahui $\mathrm{F}_{\text {hit }}$ hasil post-test kelompok eksperimen dan kelompok kontrol adalah 1,215. Sedangkan $\mathrm{F}_{\mathrm{tab}}$ dengan $\mathrm{db}_{\text {pembilang }}=35, \mathrm{db}$ penyebut $=31$, dan taraf signifikansi $5 \%$ adalah 1,800. Hal ini berarti, varians data hasil post-test kelompok eksperimen dan kelompok kontrol adalah homogen.

Berdasarkan hasil pengujian prasyarat diperoleh bahwa data hasil belajar siswa kelompok eksperimen dan kontrol berdistribusi normal dan varians kedua kelompok homogen, sehingga untuk menguji hipotesis menggunakan uji-t dengan rumus polled varians. Rekapitulasi hasil perhitungan uji-t antar kelompok eksperimen dan kontrol disajikan pada Tabel 6.

Tabel 6. Rekapitulasi Hasil Perhitungan Uji-t Kelompok Eksperimen dan Kelompok Kontrol

\begin{tabular}{lllllll}
\hline Data & Kelompok & $\mathbf{N}$ & $\bar{X}$ & $\mathbf{s}^{\mathbf{2}}$ & $\mathbf{t}_{\text {hit }}$ & \multirow{2}{*}{$\mathbf{t}_{\text {tab }}$ (t.s. 5\%) } \\
\hline Hasil & Eksperimen & 36 & 25,38 & 25,61 & \multirow{2}{*}{2,7327} & \multirow{2}{*}{1,9965} \\
\cline { 2 - 6 } Belajar & Kontrol & 32 & 22,21 & 21,07 & & \\
\hline
\end{tabular}

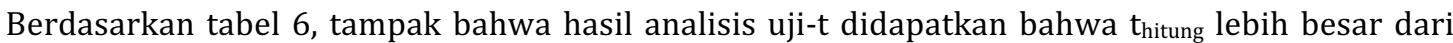
pada $t_{\text {tabel }}$ yaitu 2,7327 > 1,9965 pada derajat kebebasan 66. Hal tersebut menunjukkan bahwa $\mathrm{H}_{0}$ ditolak dan $\mathrm{H}_{1}$ diterima. Dengan demikian, dapat diinterpretasikan bahwa terdapat perbedaan yang signifikan hasil belajar antara kelompok siswa yang dibelajarkan dengan menggunakan pendekatan saintifik dalam proses menanya berbantuan Snowball Throwing dan kelompok siswa yang dibelajarkan dengan pembelajaran konvensional pada kelas III SD di Sekolah Rintisan Kurikulum 2013 Kabupaten Buleleng tahun pelajaran 2016/2017.

Berdasarkan uji hipotesis diperoleh $t_{\text {hitnung }}=2,7327$ sedangkan pada taraf signifikansi $5 \%$ dan dk $=$ 66 diperoleh nilai $t_{\text {tabel }}=1,9965$ sehingga $t_{\text {hitnung }}=2,7327>t_{\text {tabel }}=1,9965$. Dengan demikian, hipotesis nol (Ho) ditolak. Hal ini menunjukan bahwa terdapat perbedaan yang signifikan hasil belajar siswa antara kelompok siswa kelas III SD di Sekolah Rintisan Kurikulum 2013 Kabupaten Buleleng Tahun Pelajaran 2016/2017 yang dibelajarkan dengan pendekatan saintifik dalam proses menanya berbantuan snowball throwing dan kelompok siswa yang mengikuti pembelajaran konvensional pada tema energi dan perubahannya.

Berdasarkan deskripsi data hasil penelitian, kelompok siswa yang mengikuti pembelajaran dengan pendekatan saintifik dalam proses menanya berbantuan snowball throwing memiliki rata-rata skor hasil belajar yang lebih tinggi dibandingkan dengan kelompok siswa yang mengikuti pembelajaran dengan menerapkan pembelajaran konvensional. Tinjauan ini didasarkan pada rata-rata skor hasil belajar siswa. Rata-rata skor hasil belajar siswa yang mengikuti pembelajaran dengan pendekatan saintifik dalam proses menanya berbantuan snowball throwing adalah 25,30 dan rata-rata skor hasil belajar siswa yang mengikuti pembelajaran dengan pembelajaran konvensional adalah 22,21.

Berdasarkan hasil temuan tersebut, dapat dinyatakan kedua kelompok sampel penelitian yang memiliki kemampuan setara, setelah diberikan perlakuan berupa pembelajaran dengan pendekatan saintifik dalam proses menanya berbantuan snowball throwing dan mengikuti pembelajaran menggunakan pembelajaran konvensional diperoleh hasil belajar siswa yang berbeda. Hal ini dapat juga dilihat dari $\bar{X}$ siswa yang mengikuti pembelajaran menggunakan pendekatan saintifik dalam proses menanya berbantuan snowball throwing lebih tinggi dibandingkan dengan $\bar{X}$ siswa yang mengikuti pembelajaran konvensional, dalam hal ini adalah pembelajaran yang hanya menggunakan pendekatan 
saintifik. Perbedaan hasil belajar siswa dengan perolehan nilai rerata yang lebih tinggi pada kelompok eksperimen dibandingkan kelompok kontrol.

Perbedaan hasil belajar antara kelompok siswa yang mengikuti pembelajaran dengan pendekatan saintifik dalam proses menanya berbantuan snowball throwing dan kelompok siswa yang mengikuti pembelajaran dengan pembelajaran konvensional disebabkan karena perbedaan perlakuan pada langkah-langkah pembelajaran. Kegiatan pembelajaran dengan pendekatan saintifik dalam proses menanya berbantuan snowball throwing berjalan dengan optimal dan kondusif. Hal ini disebabkan oleh pendekatan saintifik dalam proses menanya berbantuan snowball throwing merupakan suatu inovasi pembelajaran yang mendorong motivasi siswa untuk bertanya sehingga mereka akan mampu mengembangkan rasa ingin tahunya. Selama kegiatan pembelajaran siswa lebih aktif karena kegiatan pembelajaran menggunakan pendekatan saintifik dalam proses menanya berbantuan snowball throwing dapat menciptakan lingkungan belajar yang menyenangkan.

Hal tersebut sesuai dengan teori yang diungkapkan Sardiman (2014: 102), dalam belajar, motivasi dapat dikatakan sebagai seluruh daya penggerak di dalam diri siswa yang menimbulkan dan memberikan arah kegiatan belajar. Dengan demikian, siswa lebih memahami materi yang diberikan sekaligus mampu mengaplikasikan dalam kehidupan sehari - hari.

Selama proses pembelajaran berlangsung semua siswa terlibat dan dituntut berpartisipasi aktif. Guru dalam pembelajaran bertugas sebagai fasilitator dan motivator, siswa diberikan waktu untuk mengumpulkan informasi dan berdiskusi bersama kelompoknya. Hal ini sejalan dengan pandangan Farhan (dalam Sandi, 2014), model pembelajaran snowball throwing merupakan salah satu model pembelajaran kooperatif learning dimana dalam pembelajaran ini terdapat kerjasama antar kelompok, saling ketergantungan antar siswa lainnya dalam kelas.

Dalam pembelajaran dengan pendekatan saintifik, inovasi aktivitas pembelajaran berbantuan Snowball Throwing akan diterapkan pada langkah menanya. Pada langkah menanya siswa dapat menyampaikan permasalahan dalam bentuk tertulis pada sebuah kertas sehingga mengatasi rasa malu siswa ketika bertanya. Kemudian kertas yang telah berisi pertanyaan siswa di remas berbentuk bulat dan dilemparkan kepada anggota kelompok lain. Setelah siswa mendapat satu bola atau satu pertanyaan diberikan kesempatan kepada siswa untuk menjawab pertanyaan yang tertulis dalam kertas berbentuk bola tersebut secara bergantian. Kegiatan pembelajaran mampu membentuk suasana kelas yang dinamis, karena kegiatan tidak hanya berpikir, menulis, bertanya atau berbicara, tetapi siswa juga melakukan aktivitas fisik yaitu menggulung kertas dan mlemparkan pada siswa lain.

Hal tersebut sesuai dengan penjelasan dari Hanafiah dan Suhana (2012: 23), proses aktivitas pembelajaran harus melibatkan seluruh aspek psikofisis peserta didik, baik jasmani maupun rohani sehingga akselerasi perubahan perilakunya dapat terjadi secara tepat, mudah, dan benar baik berkaitan dengan aspek kognitif, afektif maupun psikomotor. Dengan demikian kegiatan pembelajaran yang dirasakan siswa memenuhi tiga aspek penting.

Berbeda halnya pada kelompok kontrol, kegiatan pembelajaran konvensional yang hanya menggunkaan pendekatan saintifik berjalan kurang optimal. Hal ini disebabkan siswa masih kurang memiliki motivasi untuk bertanya. Guru kerap kesulitan melaksanakan langkah menanya karena kurang keaktifan siswa dalam mengajukan pertanyaan sehingga tahap menanya kerap terlewati begitu saja. Hanya ada beberapa siswa yang mau mengajukan pertanyaan. Guru kerap memancing siswa dengan memberikan pertanyaan, namun hanya beberapa siswa yang menjawab pertanyaan yang diberikan oleh guru.

Dengan demikian, perbedaan hasil belajar siswa dapat terlihat dari langkah pembelajaran yang dilakukan pada kedua kelompok tersebut, hasil analisis uji hipotesis, dan nilai rerata kelompok siswa yang mengikuti pembelajaran menggunakan pendekatan saintifik dalam proses menanya berbantuan snowball throwing dan siswa yang mengikuti pembelajaran konvensional.

Hasil penelitian lain yang juga mendukung keefektifan penggunaan pendekatan saintifik dalam proses menanya berbantuan snowball throwing adalah hasil penelitian yang dilakukan oleh Ni Luh Putu Wina Septiandani (2016) yang menunjukkan adanya peningkatan rata-rata presentasi hasil belajar pengetahuan muatan IPA dikarenakan penerapaan pendekatan saintifik berbasis model snowball throwing berbantuan media audiovisual pada siswa kelas VC di SDN 17 Dauh Puri Denpasar. I Komang Suka Wardhiana (2013). Hasil dalam penelitian menunjukan bahwa penerapan model Pembelajaran Kooperatif Tipe Snowball Throwing pada pembelajaran PKn dapat meningkatkan keaktifan dan hasil belajar. I Ketut Sandi (2014) menyimpulkan penerapan model pembelajaran snowball throwing lebih unggul meningkatkan kemampuan berpikir kreatif

Implikasi dalam penelitian ini adalah pemilihan kegiatan pembelajaran yang tepat dapat berpengaruh pada pencapaian hasil belajar siswa. Hasil belajar siswa secara optimal dapat dicapai jika kegiatan pembelajaran dapat mendorong dan mengaktifkan siswa dalam mengikuti pembelajaran, salah 
satunya adalah kegiatan pembelajaran yang mampu memotivasi keberanian siswa dalam bertanya. Pendekatan saintifik dalam proses menanya berbantuan snowball throwing merupakan salah satu inovasi kegiatan pembelajaran yang dapat mengatasi kesulitan siswa dalam bertanya.

Penelitian ini membuktikan bahwa pendekatan saintifik dalam proses menanya berbantuan snowball throwing baik diterapkan dalam pembelajaran sebagai upaya meningkatkan hasil belajar siswa. Dalam kegiatan pembelajaran, siswa dapat menuliskan pertanyaan yang berkaitan dengan materi yang dibahasa dalam sebuah kertas, dengan demikian akan mengembangkan sikap atau rasa ingin tahu dan mengembangkan kemampuan berpikir siswa serta mengatasi rasa malu siswa dalam penyampaian secara lisan sehingga siswa akan mendapatkan pengetahuan yang bermakna dan hasil belajar siswa akan meningkat.

Selain itu, kertas yang telah berisi pertanyaan diremas menjadi bulatan dan dilemparkan kepada anggota kelompok lainnya. Suasana pembelajaran terasa menyenangkan bagi siswa karena sesuai dengan tingkat perkembangan kelas III (kelas rendah) masih senang untuk bermain. Dengan memilih kegiatan yang menyenangkan dan sesuai dengan tingkat perkembangan siswa, maka akan mampu menarik minat dan keaktifan siswa dalam mengikuti pembelajaran. Pendekatan saintifik dalam proses menanya berbantuan snowball throwing dapat diunggulkan dalam rangka meningkatkan hasil belajar siswa. Hasil penelitian ini juga dapat digunakan sebagai bahan masukan bagi guru untuk memilih dan menerapkan kegiatan yang inovatif dan bervariasi dalam mengajar. Salah satunya adalah dengan menerapkan pendekatan saintifik dalam proses menanya berbantuan snowball throwing.

Berdasarkan penjelasan mengenai perbedaan hasil belajar siswa antara siswa yang belajar dengan pendekatan saintifik dalam proses menanya berbantuan snowball throwing dan siswa yang belajar dengan pembelajaran konvensioal, serta didukung oleh beberapa hasil penelitian yang telah dilakukan mengenai penerapaan pendekatan saintifik berbasis model snowball throwing diketahui bahwa kelompok siswa yang mengikuti pembelajaran dengan pendekatan saintifik dalam proses menanya berbantuan snowball throwing memiliki hasil belajar yang lebih tinggi dibandingkan dengan kelompok siswa yang mengikuti pembelajaran konvensional. Oleh karena itu, terdapat perbedaan yang signifikan kemampuan hasil beajar siswa antara kelompok siswa yang belajar dengan menggunakan pendekatan saintifik dalam proses menanya berbantuan snowball throwing dan kelompok siswa yang belajar dengan menggunakan pembelajaran konvensional pada tema mata kelas III SD di Sekolah Rintisan Kurikulum 2013 Kabupaten Buleleng Tahun Pelajaran 2016/2017.

\section{Simpulan Dan Saran}

Berdasarkan hasil analisis data terdapat perbedaan yang signifikan hasil belajar kelompok siswa yang dibelajaran dengan Pendekatan saintifik dalam proses menanya berbantuan Snowball Throwing dan kelompok siswa yang dibelajarkan dengan menggunakan pembelajaran Konvensional pada kelas III SD di Sekolah Rintisan Kurikulum 2013 tahun pelajaran 2016/2017.

Diperoleh $t_{\text {hitnung }}=2,7327$ sedangkan pada taraf signifikansi $5 \%$ dan $\mathrm{dk}=66$ diperoleh nilai $\mathrm{t}_{\text {tabel }}=$ 1,9965 sehingga $t_{\text {hitnung }}=2,7327>t_{\text {tabel }}=1,9965$. Dengan demikian, hipotesis nol (Ho) ditolak. Hal ini berarti terdapat perbedaan yang signifikan hasil belajar siswa antara kelompok siswa kelas III SD di Sekolah Rintisan Kurikulum 2013 Kabupaten Buleleng Tahun Pelajaran 2016/2017 yang dibelajarkan dengan pendekatan saintifik dalam proses menanya berbantuan snowball throwing dan kelompok siswa yang mengikuti pembelajaran konvensional pada tema energi dan perubahannya.

Berdasarkan hasil penelitian maka dapat diajukan beberapa saran sebagai berikut. (1) Siswasiswa di sekolah dasar agar dapat mengembangkan rasa ingin tahu dalam memperoleh pengetahuan serta mengatasi rasa malu dengan cara ikut berperan aktif selama proses pembelajaran berlangsung misalnya dengan aktif bertanya. (2) Guru-guru di sekolah dasar agar lebih berinovasi dalam pembelajaran salah satunya dengan pendekatan saintifik dalam proses menanya berbantuan snowball throwing untuk dapat meningkatkan motivasi dan keaktifan siswa dalam mengikuti pembelajaran sehingga hasil belajar siswa meningkat, (3) Sekolah-sekolah yang mengalami permasalahan rendahnya motivasi siswa dalam bertanya sehingga mengakibatkan rendahnya hasil belajar siswa, hendaknya senantiasa meningkatkan kualitas pembelajarannya dengan cara mengimplementasikan pembelajaran yang inovatif, salah satunya adalah dengan menerapkan pendekatan saintifik dalam proses menanya berbantuan snowball throwing. (4) Peneliti yang berminat untuk mengadakan penelitian lebih lanjut tentang mpendekatan saintifik dalam proses menanya berbantuan snowball thworing dalam bidang pendidikan agar memperhatikan kendalakendala yang dialami dalam penelitian ini sebagai bahan pertimbangan untuk perbaikan dan penyempurnaan penelitian yang akan dilaksanakan. 


\section{Daftar Pustaka}

Agung, A. A. Gede. 2014. Buku Ajar Metodologi Penelitian Pendidikan. Malang: Aditya Media Publishing.

Ayu, P., Indah, H., Nurjaya, I. G., Ayu, S., \& Sriasih, P. (2015). Analisis Keterampilan Bertanya Guru Dan Siswa Dalam Pembelajaran Bahasa Indonesia Di Kelas X Tav 1 Smk Negeri 3 Singaraja Jurusan Pendidikan Bahasa dan Sastra Indonesia, (1).

Japa, I Gusti Ngurah dan I Made Suarjana. 2015. Pendidikan Matematika III Berpendekatan PMRI \& Perubahan Konseptual. Singaraja: Universitas Pendidikan Ganesha.

Hanafiah, Nanang dan Cucu Suhana. 2012. Konsep Strategi Journal of Education Research and Evaluation Pembelajaran. Bandung: PT Refika Aditama

Febrian Kurniasari, Elisabet., Eunice Widyanti Setyaningtyas. (2017). Peningkatan Hasil Belajar IPS Melalui Penerapan Model Pembelajaran Kooperatif Tipe Think Pair and Share (TPS) dengan Teknik Gallery Walk.. Vol. 1 No. 2.

Kosasih, 2016. Strategi Belajar dan Pembelajaran Implementasi Kurikulum 2013. Bandung: Yrama Widya

Kristiantari, M. R. (2014). Analisis Kesiapan Guru Sekolah Dasar Dalam Mengimplementasikan Pembelajaran Tematik Integratif Menyongsong Kurikulum 2013, 3(2), 460-470.

Kurniasih, Imas dan Berlin Sani. 2014. Sukses Mengimplementasikan Kurikulum 2013. Jakarta: Kata Pena

Luh, N., Widyani, S., Suwatra, I. I. W., \& Widiana, I. W. (2017). The Discrepancy of Curriculum 2013 in Teaching and Learning Process Based on Permendikbud No 65 of 2013 in SD Laboratorium Undiksha, 1(65), 57-64

Luh, N., Wina, P., Ardana, I. K., \& Kristiantari, M. G. R. (2016). Penerapan Pendekatan Saintifik Berbasis Snowball Throwing Berbantuan Media Audiovisual Untuk Meningkatkan Hasil Belajar Pengetahuan Muatan Ipa Siswa Kelas VC SDN 17 Dauh Puri Tahun Ajaran 2015 / 2016.

Murniasih, T. R. (2007). Peningkatan Keaktifan Mahasiswa Pada Pembelajaran Pengembangan Media Manipulatif Melalui Strategi Snowball Throwing, (1), 691-697.

Peraturan Menteri Pendidikan dan Kebudayaan Republik Indonesia No. 57 Tahun 2014 tentang kurikulum 2013 tersedia pada http://pgmi.uinsuka.ac.id/media/dokumen_akademik/20160310_Permendikbud\%20Nomor\%20057\%20Tahun\% 202014.pdf (diakses tanggal 6 Januari 2017)

Rahman, A. (2014). Penerapan Metode Snowball Throwing Untuk Meningkatkan Hasil Belajar IPS Siswa Kelas V Pada SDN No. 1 Pantolobete, 5(4), 154-167.

Rita, O., Amrazi, \& Rustiyarso. (2016). Kesulitan Guru Dalam Penerapan Pendekatan Saintifik Kurikulum 2013 Kasus Pada Guru Sosiologi Di SMA. Kalimantan: UNTAN. Retrieved from http://jurnal.untan.ac.id/index.php/jpdpb/article/view/17225

Sandi, I. K., Suwatra, I. W., \& Widiana, I. W. (2014). Pengaruh Model Pembelajaran Snowball Throwing Terhadap Hasil Belajar Ipa Dengan Kovariabel Kemampuan Berpikir Kreatif Siswa Kelas IV SD Jurusan Pendidikan Guru Sekolah Dasar , FIP Universitas Pendidikan Ganesha Singaraja , Indonesia, (1).

Sani, Ridwan Abdullah. 2015. Pembelajaran Saintifik untuk Implementasi Kurikulum 2013. Jakarta : PT Bumi Aksara

Sari, M. (2015). Penggunaan model listening team sebagai sarana meningkatkan kemampuan bertanya pada pembelajaran ipa siswa kelas x smk yp 17-2 madiun, 2(1), 23-28.

Sardiman, A.M. 2007. Interaksi dan Motivasi Belajar Mengajar. Jakarta : PT RajaGrafindo Persada.

Shoimin, Aris. 2014. 68 Model Pembelajaran Inovatif dalam Kurikulum 2013. Yogyakarta: AR-RUZZ Media

Sugiyono. 2015. Metode Penelitian Pendidikan (Pendekatan Kuantitatif, Kualitatif dan R\&D). Bandung: Alfabeta

Wahyudhiatmika, P., Kt, D. B., Semara, N., \& Abadi, I. B. G. S. (2015). Proses Pembelajaran Dengan Pendekatan Saintifik Pada Kurikulum 2013 ( Tema Sejarah Peradaban Indonesia) Di Kelas V Sd 
Negeri 7 Sesetan Kecamatan Denpasar Selatan Jurusan Pendidikan Guru Sekolah Dasar, FIP Universitas Pendidikan Ganesha Singaraja , Indonesia, 2013.

Wardhiana, I. K. S., Asri, I. G. A. A. S., \& Suniasih, N. W. (2013). Penerapan Model Pembelajaran Kooperatif Tipe Snowball Throwing Untuk Meningkatkan Keaktifan Dan Hasil Belajar Pkn Kelas V SD Negeri 1 Bungbungan

Wijana, Nyoman. (2015). Pengaruh Pengintegrasian Pendidikan Karakter Berorientasi Kearifan Lokal Ke Dalam Materi Ajar Mata Kuliah Ilmu Lingkungan Untuk Meningkatkan Soft Skill Mahasiswa Jurusan Pendidikan Biologi Fmipa Undiksha. Jurnal Pendidikan Indonesia. Vol. 4, No.2. 645-657.

Yuni Suantini, Ni LP., I Nym Jampel, I Wyn Widiana. (2013). Pengaruh Model Pembelajaran Kooperatif Tipe CIRC Terhadap Pemahaman Konsep IPA Siswa Kelas IV di Gugus II Kecamatan Gerokgak. Mimbar PGSD. Vol. 1 No. 1. 